\title{
KINEMATICAL STRATEGY TO REGAIN BALANCE DURING A FORWARD FALL ON A SLIPPERY FLOOR
}

\author{
PeI-HSI CHOU*, You-Li CHOU ${ }^{\star \star}$, SHANG-LiN LeE ${ }^{\star \star}$, \\ JIA-YUAN YOU ${ }^{\star \star}$, FONG-CHIN SU ${ }^{\star \star}$, HSIEH-CHIN CHEN ${ }^{\star \star \star}$ \\ *Department of Orthopedic Surgery, Kaohsiung Medical University, Kaohsiung \\ **Institute of Biomedical Engineering, National Cheng Kung University, Tainan \\ **Department of Industrial Engineering and Management, Chao Yang University \\ of Technology, Wufeng, R.O.C
}

\begin{abstract}
Slips and falls often occur in the industrial environments. They are not only caused by environmental hazards but also by some biomechanical factors related to deficient ability of postural control to arrest impending falls. The purpose of this study is to simulate the slip condition in human walking and to find out the possible related factors of biomechanics.

Eleven male and 9 female recruited were healthful without any musculoskeletal and neurological impairments. In order to provide different disturbance level, three lean angles of tilting boards were designed as 10,20, 30 degrees with respect to horizontal plane. Subjects wore a safety harness, stood on the tilting board and were released without awareness. A forceplate applied a soap patch was in front of the tilting board to serve the slippery perturbation and to measure the foot/floor reactions. Movements of body segments were measured using the motion analysis system.

The results were shown that lean angle had a significant effect to all parameters except step length, response time, maximum ankle forward velocity, hip forward velocity, and ankle flex angle. The gender significantly affected on the step length, response time, maximum ankle forward velocity, and knee forward velocity. Larger lean angle made subjects to take a more rapid step. In order to absorb the shock in foot strike, subjects flexed more their knee and increased the foot landing angle in larger lean angle. Male tended to adopt the long step-length strategy to respond to the slippery perturbation and female tended to use the short step-length strategy instead. The results of maximum ankle forward velocity suggested that short step-length strategy could be better to reduce the foot slip than long step-length strategy.
\end{abstract}

Biomed Eng Appl Basis Comm, 2001 (February); 13: 27-32.

Key words: Slip, Kinematics, Forward fall, Step length

\section{INTRODUCTION}

Received: Jan. 16, 2001; accepted: Fcb.10, 2001

Address for correspondence: You-Li Chou, PhD; Institute of Biomedical Engineering,

National Cheng Kung University, \#1 University Road. Tainan, Taiwan, ROC.

Tel: 886-6-235-2645; Fax: 886-6-275-0621;
Slips and falls usually occur in the industrial environment. Construction workers, cleaning personnel, transportation workers, and restaurant serving personnel often walk on wet or contaminated surfaces and move materials (e.g., pushing, pulling, and carrying objects) $[1,2]$. In Sweden, foot slips are reported to account for about $11 \%$ of all occupational injuries, of which $44 \%$ were on a level-walking surface [3]. In the U.S., $17 \%$ of all disabling work injuries are attributed to falls (both from level walking and from heights) [4]. The Taiwan Council of Labor Affairs reports that 
$10.72 \%$ of all occupational injuries are caused by slips and falls [5].

Falls or slips are not only caused by environmental hazards but also by some biomechanical factors related to deficient ability of postural control to arrest impending falls $[3,6,7,8]$. Restoration of postural balance upon falls or slips is accomplished by complex neural and motor control mechanisms. This in turn requires sensory inputs from visual, vestibular and proprioceptive sensing system, appropriate organization of needed responses and abilities to meet the biomechanical requirements of those responses. Full knowledge of the biomechanics in restoration of perturbed balance will provide the achievement of the basic scientific goal to understand how postural control systems function.

Most previous studies have attempted to design both anti-slip equipment and standardized slipresistance measurement methods $[1,2,3,9,10]$. Few studies have been conducted to investigate the balance response to slip while subjects levelly walk and step on a soap patch on the floor $[3,11,12]$. From our previous investigations, modifications of posture are found in slippery perturbation but cannot seem to efficiently prevent people from falling. Smaller excursion and faster velocity of center of mass with respect to the stance foot are important for subjects regaining balance from heel strike to contralateral toe off $[11,12]$. Research is proposed to examine the biomechanical response in the arrest of impending forward falls over the slippery perturbation and the maintenance of the postural balance. A null hypothesis tested is that gender and lean angle do not affect step length, response time, maximum ankle forward velocity and some se-

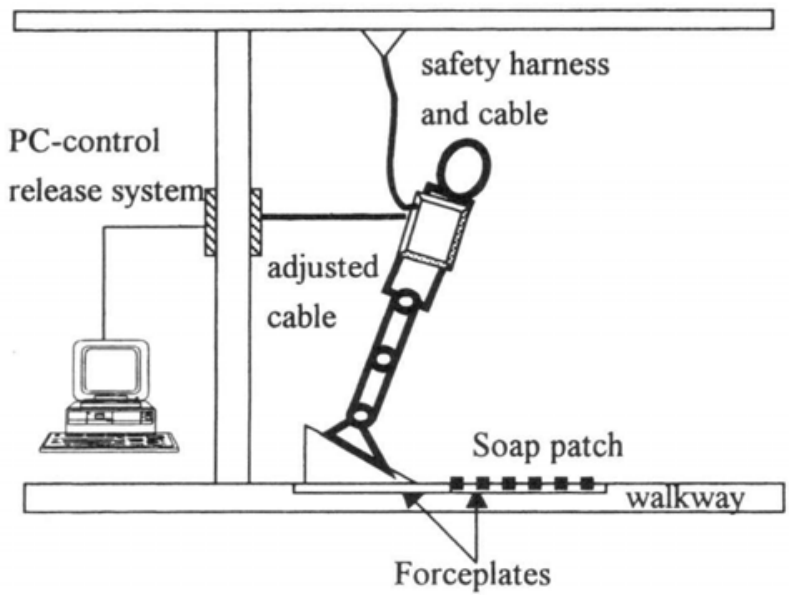

Fig. 1. Schematic sketch of experimental setup: subject, wore a safety harness, stood on a tilting board. A horizontal cable attached to the safety harness supported the subjects while they kept their bodies approximately straight in a forward leaning posture. A soap patch applied on a force plate that was in front of the subject. lective kinematical parameters at foot strike. The selective kinematical parameters included forward and downward I velocities of hip, knee and ankle, flex angle of ankle and knee, and foot landing angle.

\section{METHODOLOGY}

Eleven male and 8 female recruited in this investigation were healthy university staffs and students. Mean and standard deviation of age, height, and body weight were shown in table 1 . None had musculoskeletal, neurological and balance impairments or disease. Slip perturbation would be introduced at the heel strike of the progressing foot upon its striking on a slippery floor. As shown in Fig. 1, a safety harness tethered to support structures was used to smoothly arrest full falls and to ensure the safety of each subject. This harness did not interfere with the response during data collection. A tilting board was applied to keep subjects in initially leaning forward positions. Three lean angles of tilting boards were designed as $10,20,30$ degrees with respect to horizontal plane. A horizontal adjustable cable attached to the safety harness supported the subjects while they kept their bodies approximately straight in a forward leaning posture. Subjects stood on the tilting board and were released without awareness. A Kistler forceplates (Kistler instrument corporation, Amherst, NY) applied a soap patch was in front of the subject in order to serve the slippery perturbation and to measure the slipping foot/floor reactions. The footfloor reactions were measured using Kistler forceplate systems at rate of $1000 \mathrm{~Hz}$.

Movements of body segments are measured using the Expert Vision HiRes motion analysis system (Motion Analysis corporation, Santa Rosa, California). This system tracks the locations in space of reflective markers at rate of $60 \mathrm{~Hz}$. The reflective markers were placed on bilateral legs over the lateral malleoli, heels, toes (between second and third metatarsal heads), lateral femoral epicondyles, and greater trochanters.

A two-dimensional biomechanical model of the lower extremities was used in our previous study [11]. The lower body composite system, including pelvis, thighs, shanks and feet (two legs) are treated as a seven-segment linkage system in the model. Each segment is assumed a rigid body. Step length, response time, maximum ankle forward velocity and selective

Table1. Basic data of subjects displayed in mean (SD)

\begin{tabular}{ccc}
\hline Gender & Male & Female \\
\hline Age $(\mathrm{yrs})$ & $26.1(1.9)$ & $24.1(2.2)$ \\
Height $(\mathrm{cm})$ & $167(6.4)$ & $156.6(3.5)$ \\
Weight $(\mathrm{kg})$ & $64.5(5.8)$ & $47.8(4.7)$ \\
\hline
\end{tabular}


kinematical parameters were deigned to analyze the strategies used to respond to the slippery perturbation. The selective kinematical parameters were analyzed the values at the instant when the foot contacted to the slippery floor after a subject was released and taking a rapid step, included forward and downward velocities of hip, knee and ankle, flex angle of ankle and knee, and foot landing angle. The length of the first step taken after a subject was released was used to measure the step length. The step length was normalized by the body height. The response time was defined as the time from the instant when a subject was released to the instant when the vertical ground reaction force achieved to maximum value during the first step. The ankle forward and downward velocities were defined as the differentiated result of the marker displacement over the lateral malleolus of the progressing foot in the first step, then smoothed by low-pass filtering at $6 \mathrm{~Hz}$ using a fourth-order, zero-lag Butterworth algorithm. The maximum ankle forward velocity was defined as the maximum values of ankle forward velocity from foot strike to foot off. The forward and downward velocities of knee and hip were defined as the differentiated result of the marker displacement over lateral femoral epicondyles and greater trochanters, then smoothed by low-pass filtering at $6 \mathrm{~Hz}$ using a fourthorder, zero-lag Butterworth algorithm. The foot landing angle, defined as the angle between the progressing foot and the horizontal line in the sagittal plane. The ankle flex angle was defined as the angle between the leg segment and foot segment in the sagittal plane. The knee flex angle was defined as the angle between the thigh segment and leg segment in the sagittal plane. Descriptive statistics were calculated for the step length, response time and some selective kinematical parameters. The repeated measure analysis of variance (RM ANOVA) was performed to test the effects of lean angle and gender. The mean of whole data in step length was calculated as a standard in order to investigate the step length strategy. The strategy of a subject would be regarded as "long step-length", if the step length of the subject was larger than the mean of whole data in step length. The "short step-length" was

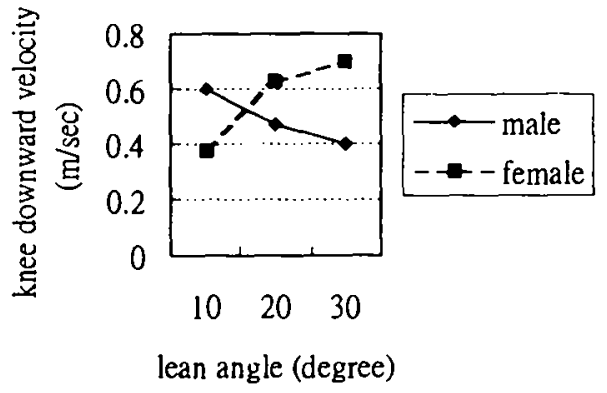

Fig. 2. The interaction between gender and lean angle in the knee downward velocity was represented. defined as that step length of the subject was smaller than the mean of whole data in step length. Descriptive statistics were used to investigate the relation of the step-length strategy with other kinematical parameters among each group of lean angle. Statistical analysis utilized the computer software SPSS for Windows 7.0, and only values of $P<0.05$ were considered significant.

\section{RESULTS}

As shown in Table 2, the parameters for each lean angle and gender, as overall results, were listed. The lean angle had a significant effect on all parameters except step length, response time, maximum ankle forward velocity, hip forward velocity, and ankle flex angle. The step length, response time, maximum ankle forward velocity, and knee forward velocity were sig. nificantly affected by the gender (Table 2 ).

\subsection{The effect of lean angle}

The larger lean angle made subjects to take a more rapid step. As shown in Table 2, the most of the forward and downward velocities in the progressing limb were significantly larger in the larger lean angle except the maximum ankle forward velocity and hip forward velocity at foot strike $(p<0.001$ for ankle forward and downward velocities, $p<0.005$ for knee forward velocity, $\mathrm{p}<0.001$ for knee downward velocity, $\mathrm{p}<0.005$ for hip downward velocity). The knee joint of the progressing limb were flexed significantly more as the lean angle increased $(p<0.05)$. The foot landing angle was significantly larger in the larger lean angle $(p<0.01)$.

\subsection{The effect of gender}

The normalized step length for the male was significantly larger than the female $(p<0.05)$. The maximum ankle forward velocity was significantly greater in male than in female $(p<0.05)$. The knee forward velocity in malc was significantly larger than those in female $(p<0.05)$. The gender and lean angle significantly interacted in the knee and hip downward velocities the floor as shown in Figure 2 and 3 ( $p<0.001$ for knee and $p<0.005$ for hip). The knee downward velocity decreased as lean angle increased in male, but it increased as the lean angle increased in female. The hip downward velocity in female increased as lean angle increased, but that in male first decreased in 20 degree of lean angle, then increased in $\mathbf{3 0}$ degree of lean angle.

\subsection{The effect of step-length strategy}

Eleven subjects adopted long step-length strategy in 10 degree of lean angle, 9 subjects adopted long step-length strategy in 20 or 30 degree of lean angle. 
Male tended to adopt the long step-length strategy and female tended to use the short step-length strategy instead (Table 3). As shown in Table 4, the step length, forward and downward velocities of hip, knee, and ankle, knee and ankle flex angle, and foot landing angle were grouped by the long and short step-length strategies in three different lean angle. The maximum ankle forward velocity was lager in long step-length strategy than in short step-length strategy except in 30 degree of lean angle. At foot strike, the ankle forward velocity was larger in short step-length strategy than in long step-length strategy. The knee and hip forward velocities were smaller in short step-length strategy than in long step-length strategy. The ankle flex angle was smaller in short step-length strategy than in long steplength strategy. The knee flex angle was larger in short step-length strategy than in long step-length strategy. The foot landing angle was larger in short step-length strategy except in 10 degree of lean angle.

\section{DISCUSSION}

Slip accidents usually occur when people are unaware of a slippery patch over the floor. Most of the previous studies about slip are conducted in which subjects are aware of the slippery danger. Modification of posture may occur before the feet of subjects contacted to the slippery floor [11]. A great benefit of the experiment design in our investigation is to prevent such modification, because subjects are forced to take a rapid step on slippery floor unaware by a forward fall.

Table 2. Parameter values for gender and three levels of leaning forward, expressed in mean (SD)

\begin{tabular}{|c|c|c|c|c|c|c|}
\hline Gender & male & male & male & female & female & female \\
\hline Lean angle & 10 degree & 20 degree & 30 degree & 10 degree & 20 degree & 30 degree \\
\hline $\begin{array}{l}\text { Step length normalized by body } \\
\text { height }\end{array}$ & $\begin{array}{l}y 0.35 \\
(0.08)\end{array}$ & 0.32 & 0.32 & & & \\
\hline Response time ${ }^{G}$ & 77.9 & 73.6 & 73.3 & 156.4 & 102.8 & 55.9 \\
\hline (ms) & (51) & (41.1) & (45.7) & (95.5) & (45) & $(38.2)$ \\
\hline $\begin{array}{l}\text { Maximum ankle forward velocity } \\
(\mathrm{m} / \mathrm{sec})\end{array}$ & $\begin{array}{l}y 2.74 \\
(1.36)\end{array}$ & $\begin{array}{l}3.01 \\
(1.22)\end{array}$ & $\begin{array}{l}3.25 \\
(0.87)\end{array}$ & $\begin{array}{l}1.92 \\
(0.92)\end{array}$ & $\begin{array}{l}2.25 \\
(1.25)\end{array}$ & $\begin{array}{l}2.35 \\
(0.97)\end{array}$ \\
\hline Parameters at foot strike & & & & & & \\
\hline Ankle forwa & $\begin{array}{l}0.93 \\
(0.93)\end{array}$ & $\begin{array}{l}1.55 \\
(0.67)\end{array}$ & $\begin{array}{l}2.06 \\
(1.31)\end{array}$ & $\begin{array}{l}0.98 \\
(0.06)\end{array}$ & $\begin{array}{l}1.15 \\
(0.84)\end{array}$ & $\begin{array}{l}1.33 \\
(1.1)\end{array}$ \\
\hline $\begin{array}{l}\text { Ankle downward velocity } \\
(\mathrm{m} / \mathrm{sec})\end{array}$ & $\begin{array}{l}{ }^{\mathrm{L}} \mathrm{0.37} \\
(0.25)\end{array}$ & $\begin{array}{l}0.64 \\
(0.41)\end{array}$ & $\begin{array}{l}0.88 \\
(0.3)\end{array}$ & $\begin{array}{l}0.35 \\
(0.2)\end{array}$ & $\begin{array}{l}0.61 \\
(0.28)\end{array}$ & $\begin{array}{l}0.56 \\
(0.24)\end{array}$ \\
\hline Knee forward velocity ${ }^{\mathrm{G}, \mathrm{L}}(\mathrm{m} / \mathrm{sec})$ & $\begin{array}{l}1.2 \\
(0.29)\end{array}$ & $\begin{array}{l}1.22 \\
(0.3)\end{array}$ & $\begin{array}{l}1.77 \\
(0.88)\end{array}$ & $\begin{array}{l}0.32 \\
(0.38)\end{array}$ & $\begin{array}{l}1.01 \\
(0.38)\end{array}$ & $\begin{array}{l}1.23 \\
(0.32)\end{array}$ \\
\hline $\begin{array}{l}\text { Knee downward velocity } \\
(\mathrm{m} / \mathrm{sec})\end{array}$ & $\begin{array}{l}{ }^{L} 0.6 \\
(0.24)\end{array}$ & $\begin{array}{l}0.47 \\
(0.27)\end{array}$ & $\begin{array}{l}0.4 \\
(0.31)\end{array}$ & $\begin{array}{l}0.38 \\
(0.38)\end{array}$ & $\begin{array}{l}0.63 \\
(0.22)\end{array}$ & $\begin{array}{l}0.7 \\
(0.31)\end{array}$ \\
\hline Hip forward velocity $(\mathrm{m} / \mathrm{sec})$ & $\begin{array}{l}1.21 \\
(0.26)\end{array}$ & $\begin{array}{l}1.19 \\
(0.2)\end{array}$ & $\begin{array}{l}1.24 \\
(0.22)\end{array}$ & $\begin{array}{l}1.02 \\
(0.2)\end{array}$ & $\begin{array}{l}1.17 \\
(0.11)\end{array}$ & $\begin{array}{l}1.23 \\
(0.18)\end{array}$ \\
\hline Hip downward velocity ${ }^{\mathrm{L}}(\mathrm{m} / \mathrm{sec})$ & $\begin{array}{l}0.42 \\
(0.19)\end{array}$ & $\begin{array}{l}0.37 \\
(0.13)\end{array}$ & $\begin{array}{l}0.38 \\
(0.16)\end{array}$ & $\begin{array}{l}0.22 \\
(0.16)\end{array}$ & $\begin{array}{l}0.34 \\
(0.1)\end{array}$ & $\begin{array}{l}0.39 \\
(0.09)\end{array}$ \\
\hline $\begin{array}{l}\text { *Ankle flex angle } \\
\text { (degree) }\end{array}$ & $\begin{array}{l}13.7 \\
(7.8)\end{array}$ & $\begin{array}{l}6.2 \\
(9.5)\end{array}$ & $\begin{array}{l}4.5 \\
(8.8)\end{array}$ & $\begin{array}{l}6.6 \\
(15.1)\end{array}$ & $\begin{array}{l}6.7 \\
(13.3)\end{array}$ & $\begin{array}{l}7.1 \\
(12.9)\end{array}$ \\
\hline $\begin{array}{l}\text { Knee flex angle }{ }^{\mathrm{L}} \\
\text { (degree) }\end{array}$ & $\begin{array}{l}20.4 \\
(11.4)\end{array}$ & $\begin{array}{l}26.6 \\
(12.7)\end{array}$ & $\begin{array}{l}30 \\
(14.7)\end{array}$ & $\begin{array}{l}23.8 \\
(21)\end{array}$ & $\begin{array}{l}19.9 \\
(14.1)\end{array}$ & $\begin{array}{l}28.5 \\
(13.3)\end{array}$ \\
\hline $\begin{array}{l}\text { Foot landing angle } \\
\text { (degree) }\end{array}$ & $\begin{array}{l}10.8 \\
(5.3)\end{array}$ & $\begin{array}{l}13.4 \\
(9.3)\end{array}$ & $\begin{array}{l}16 \\
(8.4)\end{array}$ & $\begin{array}{l}10.57 \\
(5.1)\end{array}$ & $\begin{array}{l}11.78 \\
(5.7)\end{array}$ & $\begin{array}{l}17.6 \\
(8)\end{array}$ \\
\hline
\end{tabular}

* Positive values mean joint plantar flexion and negative values meant joint dorsiflexion.

The superscript $G$ denotes significantly affected by the gender. $(p<0.05)$

The superscript $L$ denotes significantly affected by the level of leaning forward. $(p<0.05)$

Table 3. The number of male and female use either long or short step-length strategies in three lean angles.

\begin{tabular}{lllllll}
\hline Gender & male & female & male & female & male & female \\
\hline Lean angle & 10 degree & 10 degree & 20 degree & 20 degree & 30 degree & 30 degree \\
\hline Long step-length strategy & 8 & 3 & 7 & 2 & 6 & 3 \\
Short step-length strategy & 3 & 6 & 4 & 7 & 5 & 6 \\
\hline
\end{tabular}




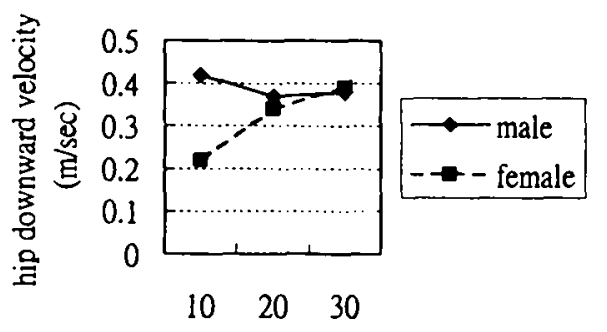

Fig. 3. The interaction between gender and lean angle in the hip downward velocity was represented.

Previous study has been shown that the mean maximum lean angle is $\mathbf{3 2 . 5}$ degree from which young can regain balance by taking a single, rapid step upon release from a forward lean [8]. Therefore, the 30 degree of maximum lean angle are rationally designed to let subjects to take a step from which subjects can regain balance by taking a single step. The psychological factors to slip and modification of posture response can be well excluded in the investigation.

The results of the investigation are shown that the subjects take a more rapid step in the larger lean angle. Physical laws dictate that a lean angle increase, the time available for balance restoration decrease. Thus, three different lean angle can well serve different levels of disturbance. Subjects flex more their knee and increase the foot landing angle in larger lean angle. These posture in knee and foot may be result from the response to shock absorption at initially foot strike [14].

Male tended to use the long step-length strategy and female tended to use the short step-length strategy instead. The long step length lowers the body center of mass, increases the area of foot support, and allows a more stable posture to be maintained on the slippery surface. Short step length is a common strategy adopted while walking on an icy or oily floor in order to transfer the body weight from one leg to the other more quickly, it makes center of mass distance and velocity shorter and faster, respectively, with reference to the stance foot $[11,15]$. The result of video records have shown that subjects does not always use the same step-length strategy to prevent slip in all tasks. For example, a subject may adopt the short step-length strategy in 10 degree of lean angle, but he may adopt the long step-length strategy in 20 degree of lean angle instead. Maximum foot slip velocity is usually used to evaluate the condition of slip $[3,11,12]$. The results of maximum ankle forward velocity suggest that short step-length strategy may be better to reduce the foot slip than the long step-length strategy. Further control research is needed to investigate whether the long or short step-length strategy will be better to regain balance for the slip perturbation.

Table 4. Parameter values for three levels of leaning forward and two step length strategies, expressed in mean (SD)

\begin{tabular}{|c|c|c|c|c|c|c|}
\hline Lean angle & 10 degree & 10 degree & 20 degree & 20 degree & 30 degree & 30 degree \\
\hline Step length strategy & long & short & long & short & long & short \\
\hline Step length normalized by & 0.37 & 0.26 & 0.34 & 0.27 & 0.35 & 0.28 \\
\hline $\begin{array}{l}\text { body height } \\
\text { Maximum ankle forward }\end{array}$ & $(0.05)$ & $\begin{array}{l}(0.04) \\
168\end{array}$ & $(0.03)$ & $(0.03)$ & $\begin{array}{l}(0.07) \\
2.74\end{array}$ & $\begin{array}{l}(0.04) \\
2.93\end{array}$ \\
\hline velocity $(\mathrm{m} / \mathrm{sec})$ & $(1.21)$ & $(0.88)$ & $(1.17)$ & (1.27) & $(0.88)$ & (1.12) \\
\hline Parameters at foot strike & & & & & & \\
\hline Ankle forward velocity $(\mathrm{m} / \mathrm{sec})$ & $\begin{array}{l}0.87 \\
(0.83)\end{array}$ & $\begin{array}{l}1.05 \\
(0.75)\end{array}$ & $\begin{array}{l}1.31 \\
(0.7)\end{array}$ & $\begin{array}{l}1.41 \\
(0.83)\end{array}$ & $\begin{array}{l}1.53 \\
(1.24)\end{array}$ & $\begin{array}{l}1.9 \\
(1.28)\end{array}$ \\
\hline $\begin{array}{l}\text { Ankle downward velocity } \\
(\mathrm{m} / \mathrm{sec})\end{array}$ & $\begin{array}{l}0.33 \\
(0.24)\end{array}$ & $\begin{array}{l}0.39 \\
(0.21)\end{array}$ & $\begin{array}{l}0.48 \\
(0.33)\end{array}$ & $\begin{array}{l}0.75 \\
(0.34)\end{array}$ & $\begin{array}{l}0.66 \\
(0.22)\end{array}$ & $\begin{array}{l}0.8 \\
(0.36)\end{array}$ \\
\hline Knee forward velocity $(\mathrm{m} / \mathrm{sec})$ & $\begin{array}{l}1.24 \\
(0.24)\end{array}$ & $\begin{array}{l}0.87 \\
(0.37)\end{array}$ & $\begin{array}{l}1.28 \\
(0.25)\end{array}$ & $\begin{array}{l}1.01 \\
(0.38)\end{array}$ & $\begin{array}{l}1.54 \\
(0.91)\end{array}$ & $\begin{array}{l}1.52 \\
(0.59)\end{array}$ \\
\hline $\begin{array}{l}\text { Knee downward velocity } \\
(\mathrm{m} / \mathrm{sec})\end{array}$ & $\begin{array}{l}0.54 \\
(0.27)\end{array}$ & $\begin{array}{l}0.46 \\
(0.34)\end{array}$ & $\begin{array}{l}0.5 \\
(0.3)\end{array}$ & $\begin{array}{l}0.58 \\
(0.22)\end{array}$ & $\begin{array}{l}0.52 \\
(0.43)\end{array}$ & $\begin{array}{l}0.56 \\
(0.27)\end{array}$ \\
\hline Hip forward velocity $(\mathrm{m} / \mathrm{sec})$ & $\begin{array}{l}1.23 \\
(0.24)\end{array}$ & $\begin{array}{l}1 \\
(0.21)\end{array}$ & $\begin{array}{l}1.25 \\
(0.19)\end{array}$ & $\begin{array}{l}1.12 \\
(0.11)\end{array}$ & $\begin{array}{l}1.29 \\
(0.17)\end{array}$ & $\begin{array}{l}1.19 \\
(0.22)\end{array}$ \\
\hline Hip downward velocity $(\mathrm{m} / \mathrm{sec})$ & $\begin{array}{l}0.35 \\
(0.16)\end{array}$ & $\begin{array}{l}0.3 \\
(0.25)\end{array}$ & $\begin{array}{l}0.36 \\
(0.12)\end{array}$ & $\begin{array}{l}0.35 \\
(0.12)\end{array}$ & $\begin{array}{l}0.4 \\
(0.12)\end{array}$ & $\begin{array}{l}0.37 \\
(0.14)\end{array}$ \\
\hline${ }^{*}$ Ankle flex angle (degree) & $\begin{array}{l}15.9 \\
(3.1)\end{array}$ & $\begin{array}{l}4 \\
(12.1)\end{array}$ & $\begin{array}{l}9.7 \\
(8.4)\end{array}$ & $\begin{array}{l}3.7 \\
(12.3)\end{array}$ & $\begin{array}{l}10.6 \\
(10.1)\end{array}$ & $\begin{array}{l}1.6 \\
(3.6)\end{array}$ \\
\hline Knee flex angle (degree) & $\begin{array}{l}18.3 \\
(13.1)\end{array}$ & $\begin{array}{l}26.4 \\
(18.9)\end{array}$ & $\begin{array}{l}20.5 \\
(11.8)\end{array}$ & $\begin{array}{l}26.1 \\
(14.7)\end{array}$ & $\begin{array}{l}23.5 \\
(14.5)\end{array}$ & $\begin{array}{l}34.1 \\
(11.4)\end{array}$ \\
\hline Foot landing angle (degree) & $\begin{array}{l}10.7 \\
(5.4)\end{array}$ & $\begin{array}{l}10.6 \\
(4.9)\end{array}$ & $\begin{array}{l}11 \\
(5.3)\end{array}$ & $\begin{array}{l}14 \\
(9.3)\end{array}$ & $\begin{array}{l}13.8 \\
(6.9)\end{array}$ & $\begin{array}{l}19.1 \\
(8.5)\end{array}$ \\
\hline
\end{tabular}

* Positive values mean joint plantar flexion and negative values meant joint dorsiflexion. 
The response time was about 77.9 to $73.3 \mathrm{msec}$ in male, and about 156.4 to $55.9 \mathrm{msec}$ for female. The reaction time was similar to those found in the earlier study of forward falls [8]. Do et al. have found that the onset of myoelectric activities occurred approximately $60 \mathrm{msec}$ following release from a forward leaning posture [16]. It was presumed that similar short latency active muscle contraction led to the short reaction times found in this study.

\section{CONCLUSION}

The larger lean angle made subjects to take a more rapid step. In order to absorb the shock at foot strike, subjects flex more their knee and increase the foot landing angle in larger lean angle. Male tended to adopt the long step-length strategy to maintain the balance for slippery perturbation, but female tended to adopt the short step-length strategy. The results of maximum ankle forward velocity suggest that short step-length strategy may be better to reduce the foot slip than long step-length strategy.

\section{REFERENCES}

1. Strandberg L: On accident analysis and slipresistance measurement. Ergonomics 1983; 26:1132.

2. Nicholson AS and David GC: Slipping, tripping and falling accidents to delivery driver. Ergonomics $1985 ; 28: 977-991$.

3. Lanshammar $\mathrm{H}$ and Strandberg $\mathrm{L}$ : The dynamics of slipping accidents. J Occup Accid 1983; 3: 153-162.

4. Council of Labor Affairs Executive Yuan, ROC: Monthly bulletin of labor statistics, Taiwan area Rebulic of China, December 1999. Council of Labor Affairs Executive Yuan, ROC 1999; 160-161.

5. National Safety Council: Accident facts. Chicago, III. National Safety Council, 1990.
6. Chen HC, Ashton-Miller JA, Alexander NB, and Schultz AB: Effects of age and available response time on ability to step over an obstacle. Joumal of Gerontology: Medical Science 1994; 49(5):M227M233.

7. Chen HC, Schultz AB, and Ashton-Miller JA: Factors underlying balance restoration after tripping: biomechanical model analyses. ASME Summ Bioengineering Conference, 1993.

8. Thelen DG, Wojcik LA, Schultz AB, AshtonMiller JA, and Alexander NB: Age difference in using a rapid step to regain balance during a forward fall. J Gerontol: Med Sci 1997; 52A: M8-13.

9. Tisserand M: Progress in the prevention of falls caused by slipping. Ergonomics 1985; 28:10271042.

10. Rosenblad-Wallin EF: The design and evaluation of military footwear based upon the concept of healthy feet and user requirement studies. Ergonomics 1988; 31(9):1245-1263.

11. Chou YL, You JY, Lin CJ, Su FC, and Chou PH: The modified gait patterns during stepping on slippery floor. The Chinese Journal of Mechanics 2000; 16(4): 349-355.

12. You JY, Chou YL, Lin CJ and Su FC: Effect of slip on movement of body center of mass relative to base of support. Clin. Biomech 2001; 16(2): 168174.

13. Winter DA: Biomechanics and motor control of human movement. John Wiley \& Soms, Inc, USA, 1990.

14.Perry J: Gait analysis: normal and pathological function. Thorofare: SLACK Inc, USA, 1992.

15. Kinoshita H: Effects of different loads and carrying systems on selected biomechanical parameters describing walking gait. Ergonomics 1985; 28: 13471362.

16. Do MC, Breniere Y, and Bouisset S: Compensatory reactions in forward fall: are they initated by stretch receptors?. Electroencephalogy Clin Neurophysiol 1988; 69: 448-452. 